\title{
TEMUAN RANGKA MANUSIA AUSTRONESIA DI PANTURA JAWA TENGAH: "Sebuah kajian awal"
}

\section{AUSTRONESIANS SKELETONS FOUND IN THE NORTH COAST OF CENTRAL JAVA: "A Preliminary Research"}

\author{
H. Gunadi Kasnowihardjo \\ Balai Arkeologi Yogyakarta \\ gunbalar@yahoo.com
}

\begin{abstract}
Preliminary research in Lasem, Sluke and Kragan Districts, Rembang Regency, Central Java has been conducted in late 2012. The first problem in this study is to reviewing the Prehistoric Burials Site at North Beach area (PANTURA) of Rembang Regency. The objective is to seek possibility of discovering several prehistoric grave sites along the coast between Kragan and Lasem Districts. By surveying the surface along the coast, was found a few locations that are identified as prehistoric grave site such in the village of Leran, Sluke District and village of Binangun, Lasem District. Based on the survey results followed by excavation to learn more about the grave sites, especially the skeleton that was buried as the main data of this research. The skeleton findings those are typical of the Austronesian culture. This finding is significant data. Even in terms of paleoanthropological study known about tooth modification in some individuals, both of which are found on Binangun and Leran. Modified forms of the teeth look likes jasmine flower buds have never been found anywhere else in Indonesia.
\end{abstract}

Keywords : Preliminary Research, North Coast of Central Java, Austronesia, Tooth Modification

\begin{abstract}
ABSTRAK
Penelitian pendahuluan di Kecamatan Lasem, Sluke dan Kragan, Kabupaten Rembang, Jawa Tengah dilaksanakan pada akhir tahun 2012. Permasalahan awal dalam kajian ini adalah mengungkap kembali situs-situs kubur prasejarah di Pantai Utara Kabupaten Rembang. Adapun tujuannya mencari kemungkinan ditemukannya situs-situs kubur prasejarah baru di sepanjang pantai utara antara Kecamatan Kragan - Kecamatan Lasem, Kabupaten Rembang, Jawa tengah. Dengan melakukan survei permukaan di sepanjang pantai tersebut, ditemukan beberapa lokasi yang diidentifikasi sebagai situs kubur prasejarah seperti di Desa Leran, Kecamatan Sluke dan di Desa Binangun, Kecamatan Lasem. Hasil survei dilanjutkan dengan ekskavasi untuk mengetahui lebih jauh tentang situs kubur tersebut, terutama rangka manusia sebagai data utama dari hasil penelitian ini. Dari hasil penelitian awal diketahui bahwa temuan rangka tersebut memiliki ciri-ciri manusia pendukung budaya Austronesia. Temuan ini merupakan data yang cukup signifikan. Bahkan dari sisi paleoantropologi ditemukan adanya modifikasi gigi pada beberapa individu, baik yang ditemukan di Binangun maupun di Leran. Modifikasi bentuk gigi menyerupai kuncup bunga melati belum pernah ditemukan di tempat lain di Indonesia.
\end{abstract}

Kata kunci: Penelitian Pendahuluan, Pantai Utara Jawa Tengah, Austronesia, Modifikasi Gigi.

Tanggal masuk : 6 Februari 2013

Tanggal diterima : 26 April 2013 


\section{PENDAHULUAN}

Di Indonesia, manusia pendukung budaya Austronesia sisa-sisanya dapat dikatakan sangat terbatas. Sementara secara artefaktual sisa-sisa budaya materinya banyak ditemukan dan tersebar di beberapa wilayah di kepulauan Indonesia. Penamaan Austronesia pada awalnya adalah penamaan yang semata-mata didasarkan atas penggolongan kebahasaan yang diperoleh melalui perbandingan bahasabahasa yang sampai kini masih digunakan oleh penduduk di wilayah yang sangat luas (Masinambow 2004). Rumpun bahasa Austronesia memiliki sekitar 1.200 bahasa dan dituturkan oleh hampir 300 juta penutur yang tersebar antara Madagaskar di barat hingga Pulau Paskah di timur dan dari Taiwan Mikronesia di utara hingga New Zealand di selatan (Bellwood 2000).

Sejauh yang dapat dikenali dan berdasarkan rekonstruksi yang disusun para ahli linguistik, komunitas Austronesia paling awal berada di Formosa (Taiwan). Hal ini seperti diungkapkan Kern dalam artikelnya berjudul Taalkundige gegevens ter bepaling van het stamland der Maleisch-
Polynensische volken yang ditulis pada tahun 1889 (Hoop 1938, 87-88). Selepas dari Taiwan, para kolonis Austronesia awal bergerak ke selatan melalui Filipina selanjutnya memasuki wilayah Indonesia dan Oceania (Bellwood 2000). Hasil kajian etnolinguistik prasejarah di atas oleh para ahli arkeologi kemudian disejajarkan dengan bukti-bukti artefaktual yang ditemukan, seperti misalnya beliung dan tembikar serta perkakas pertanian maupun kebiasaan memelihara ternak yang merupakan ciri budaya manusia penutur bahasa Austronesia (Geldern 1945; Bellwood 2000). Dengan demikian istilah Austronesia yang pada awalnya terkait dengan satu ras Mongolid, akhirnya berkembang menjadi sebutan untuk produk suatu budaya materi seperti telah disebutkan di atas. Seperti ditegaskan oleh Truman Simanjuntak (2011) bahwa terminologi "Austronesia" pada hakekatnya mengacu pada bahasa, namun dalam arti luas mengacu pada penutur dan budayanya secara keseluruhan.

Dalam perspektif waktu, studi Austronesia melingkupi rentang waktu sekitar 4000 tahun, terhitung sejak datangnya para penutur bahasa

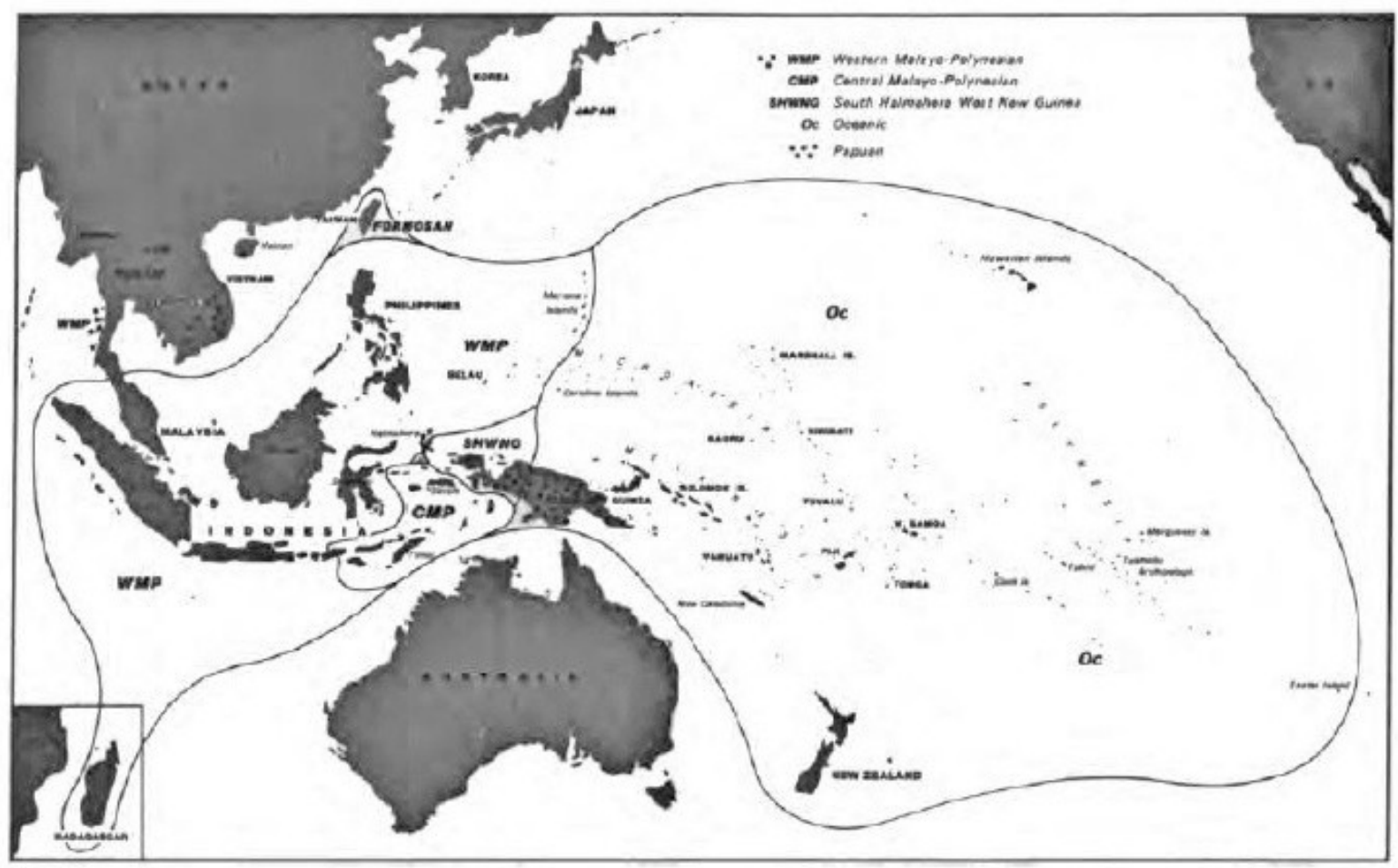

Peta 1. Sebaran penutur bahasa Austronesia (Sumber: Bellwood 2000.) 
Austronesia di kawasan Indonesia hingga sekarang. Lebih lanjut dijelaskan Simanjuntak bahwa rentang waktu di atas dapat dibagi dalam tiga kelompok berdasarkan periodisasi perkembangan budayanya. Ketiga kelompok dan periodisasi Austronesia di Indonesia tersebut adalah: Austronesia Prasejarah dalam rentang waktu antara $4000-2000$ $\mathrm{BP}$, yang ditandai oleh budaya neolitik. Kedua, Austronesia Protosejarah berkembang antara 2000 BP-abad IV/V Masehi, budaya yang menandai dalam periode ini adalah kubur tempayan dan munculnya budaya perunggu dan besi. Periode ketiga yaitu Austronesia Masa Kini dengan cakupan waktu sejak peristiwa kemerdekaan hingga sekarang, yang ciri-cirinya lepasnya manusia Indonesia dari pengaruh budaya asing dan mulainya proses terbentuknya budaya nasional (Simanjuntak 2011, 8 9).

Di pantai utara Jawa Tengah tepatnya di Desa Plawangan, Kecamatan Kragan, Kabupaten Rembang ditemukan Situs Kubur Prasejarah yang telah diteliti oleh Pusat Arkeologi Nasional pada tahun 1977 - 1978. Dari hasil penelitian tersebut diketahui ada dua tipe kubur di Situs Plawangan yaitu kubur dengan wadah (tempayan dan nekara perunggu), dan kubur tanpa wadah (terlentang). Selain temuan rangka manusia, terdapat artefak dan benda lain yang ditemukan baik yang bersamaan maupun terpisah dengan rangka tersebut, seperti tembikar, fragmen besi dan perunggu, tulang binatang, dan manik-manik. Temuan lain berupa sisa-sisa cangkang kerang baik jenis pelecypoda maupun gastropoda yang diperkirakan sebagai sisa-sisa makanan. Selain itu adapula cangkang kerang yang dgunakan sebagai alat kebutuhan sehari-hari seperti sendok atau alat pemotong, serta adapula yang dijadikan sebagai asesoris. Benda-benda tersebut diperkirakan merupakan bekal kubur yang diperuntukkan kepada si mati (Sukendar dan Awe 1981). Situs

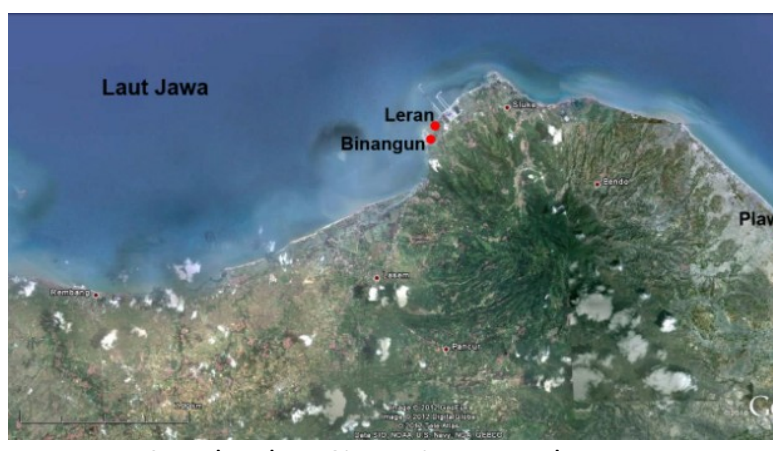

Peta 2. Keletakan Situs Binangun dan Leran

Plawangan oleh R. P. Soejono (2008) disejajarkan dengan Situs Gilimanuk dan Situs Anyer di Banten, yaitu berasal dari masa paleometalik akhir.

Sangat disayangkan, Situs Kubur Prasejarah Plawangan yang merupakan satu-satunya situs kubur yang dapat menjelaskan tentang budaya dan manusia penutur bahasa Austronesia di wilayah pantai utara Jawa Tengah, saat ini sudah tidak dapat dikenali lagi. Sebagian area situs sudah dijadikan permukiman penduduk dan Rumah Sakit. Oleh karena itu potensi kawasan di sekitar Situs Plawangan perlu diteliti kembali, terutama di area pantai utara sepanjang antara Kecamatan Kragan dan Kecamatan Lasem. Penelitian di sepanjang pantai utara tersebut terkait dengan jalur migrasi para penutur bahasa Austronesia yang mencapai Pulau Jawa. Temuan rangka manusia yang sejenis dan seumur dengan rangka-rangka yang ditemukan di Situs Plawangan akan dapat memberikan informasi menarik yang dapat melengkapi data yang sangat langka. Selain itu, situs-situs baru seperti yang ditemukan di Desa Leran, Kecamatan, Sluke dan Desa Binangun, Kecamatan Lasem, Kabupaten Rembang nantinya dapat dilestarikan dan dikonservasi sebagai sumber ilmu pengetahuan bagi masyarakat luas. Kasus seperti yang terjadi di Situs Plawangan jangan sampai terulang kembali di tempat lain. 


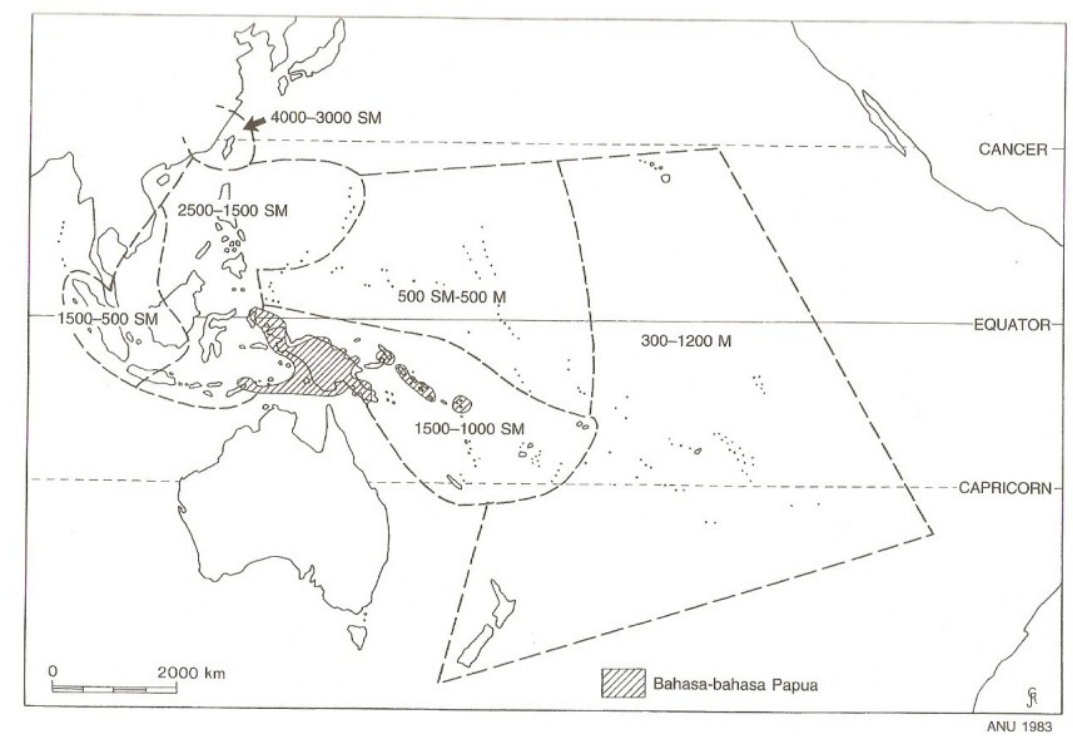

Peta 3. Migrasi Penutur Austronesia di Wilayah Indonesia antara data linguistik dan data arkeologis

(Sumber: Bellwood 2000)

\section{BAHASA DAN BUDAYA AUSTRONESIA}

H. Kern dalam teori linguistiknya menyatakan bahwa bahasa Austronesia adalah rumpun bahasa yang berasal dari bahasa Austrik, yaitu bahasa yang digunakan oleh suku bangsa yang mendiami kawasan Yunan, Tiongkok bagian selatan. Bahasa Austrik ini berkembang dan pecah menjadi dua yaitu Austro-Asiatik, bahasa yang digunakan oleh mereka yang tinggal di daratan Asia seperti misalnya bangsa Mon-Khmer dan Suku Munda di India. Kedua adalah bahasa Austronesia (AN) yaitu bahasa yang digunakan oleh suku bangsa yang mendiami kawasan kepulauan yang sangat luas. Batas di utara adalah Kepulauan Formosa sebelah barat Madagaskar, dan Kepulauan Pasifik di timur kecuali orangorang di Halmahera utara dan Papua (Hoop 1938, 87-88). Para penutur bahasa AN setelah terpisah dan tersebar di wilayah kepulauan yang sangat luas, mereka hidup berkelompok dan masingmasing kelompok mengembangkan bahasanya dan meninggalkan kebiasaan lama serta menyesuaikan dengan lingkungan baru. Setiap kelompok menemukan nama baru bagi kelompoknya sendiri (Bellwood 2000, 141). Mengacu pendapat Tryon, Bellwood menyebutkan bahwa jumlah kelompok bahasa AN mencapai 1200, merupakan rumpun bahasa terbesar di dunia yang pada waktu itu tersebar lebih dari separo belahan dunia (Bellwood 2000, 142).

Teori Hendrik Kern inilah yang akhirnya dikembangkan oleh para ahli linguistik yang dikenal dengan metode lexico-statistik yang ditemukan oleh seorang ahli linguistik bernama $M$. Swadesh. Perbendaharaan kata-kata dasar (basic vocabulary) yang bersifat universal, seperti kata-kata untuk anggota badan, gejala-gejala alam seperti bumi, langit, bintang, hujan, matahari, kata-kata untuk bilangan dan sebagainya. Basic vocabulary masing-masing anak bahasa ditentukan sejumlah 200 kata. Dari hasil analisisnya dapat diketahui bahwa apabila suatu bahasa pecah menjadi dua, maka kedua anak bahasa masing-masing akan berubah secara lambat termasuk juga kata-kata dasarnya akan mengalami perubahan. Lama-lama dari ke 200 kata akan semakin banyak yang mengalami perubahan dalam kedua anak bahasa tersebut (Koentjaraningrat 1982, 15).

Hasil analisis linguistik inilah yang diadopsi oleh para ahli arkeologi seperti Robert Von Heine Geldern dan para ahli arkeologi di masa-masa berikutnya hingga sekarang. Demikian pula dengan teori lexico-statistik yang ditemukan oleh M. Swadesh sampai saat ini terus 
dikembangkan oleh para ahli linguistik seperti misalnya Robert Blust yang bekerjasama dengan Peter Bellwood, sehingga menghasilkan model Out of Taiwan dalam menjawab dari mana asal - usul bangsa penutur bahasa Austronesia (Tanudirdjo dan Prasetyo 2004, 80-96). Seperti ditulis Bellwood (1995) bahwa asal-usul Austronesia sudah sering dibicarakan oleh para ahli baik ahli linguistik maupun ahli prasejarah. Para ahli prasejarah menyatakan bahwa tanah asal Austronesia adalah daerah yang merupakan asal pertanian primer. Dengan modal pengetahuan sistem bercocok tanam (padi-sawah) dan teknologi membuat perahu sebagai sarana transportasi inilah mereka mampu melakukan kolonisasi ke wilayah yang lebih luas dan jauh. Berdasarkan baik data arkeologi maupun data linguistik, diketahui bahwa ekspansi atau pola sebaran budaya Austronesia dimulai dari wilayah Cina Selatan dan Taiwan sejak 4000 BC.

Kajian linguistik atas asal-usul bahasa Austronesia (AN) yang mendapat banyak dukungan baik dari ahli linguistik lain maupun dari ahli prasejarah adalah pendapat yang dikemukakan Robert Blust, yang menyatakan bahwa asal-usul AN adalah Taiwan (Fernandez 2004, 4153). Dari Taiwan manusia penutur bahasa AN berjalan ke selatan yaitu ke Philipina, dari Philipina ke selatan hingga mencapai Pulau Kalimantan. Dari Kalimantan para penutur bahasa AN ada yang berjalan ke timur menuju Pulau Sulawesi dan pulau-pulau lain di bagian timur Indonesia hingga ke Polinesia. Adapula yang berjalan ke barat hingga mencapai Semenanjung Malaka, kemudian menyusuri Pulau Sumatra, hingga Pulau Madagaskar. Adakah di antara penutur bahasa AN tersebut dari Kalimantan terus berjalan ke selatan hingga mencapai Pulau Jawa? Hal inilah yang akan dibahas pada bab selanjutnya.

Von Heine Geldern ahli prasejarah yang terinspirasi teori $\mathrm{H}$. Kern kemudian mencoba menyelidiki artefak-artefak yang diperkirakan hasil budaya manusia penutur AN. Beberapa artefak tersebut antara lain kapak atau beliung persegi, gerabah slip merah dan monumen dari batu besar yang berfungsi sebagai sarana pemujaan, artefak-artefak tersebut oleh Geldern dimasukkan dalam masa Neolitik (Soejono 2008, 248-250). Selain itu, adapula budaya AN yang bersifat intangible seperti misalnya kebiasaan makan sirih-pinang, tradisi yang bersifat ritual dan kepercayaan adanya kehidupan setelah mati. Beberapa data yang bersifat intangible dapat diketahui antara lain dari sistem penguburan seperti yang ditemukan di Situs Plawangan, Situs Leran, dan Situs Binangun di pantai utara Kabupaten Rembang, Jawa Tengah.

Temuan artefak hasil penelitian Van Stein Callenfels dan Van Heekeren di situs-situs Kalumpang, Minanga-Sippako, dan Kamassi di daerah aliran sungai Karama, Sulawesi Barat seperti gerabah, beliung, dan kapak yang diupam diperkirakan pembuatannya pada masa bercocok tanam. Demikian pula artefak yang ditemukan dari penelitian yang dilakukan oleh Peter Bellwood dan Sutayasa di situs Paso, tepi barat Danau Tondano, Sulawesi Utara, menunjukkan adanya tipe gerabah yang diduga berasal dari masa bercocok tanam (Soejono 2008, 231-233). Selanjutnya penelitian di daerah aliran sungai Karama oleh Harry Truman Simanjuntak antara lain menemukan artefak seperti gerabah slip merah dan gerabah kasar berhias. Pertanggalan absolut gerabah slip merah diketahui antara 3500 - 3000 BP, sedangkan pertanggalan gerabah kasar berhias antara 3000 - 2500 BP. Lebih lanjut dijelaskan oleh Simanjuntak (2007 dan 2008, 73) bahwa gerabah slip merah diperkirakan didatangkan dari luar Sulawesi. Penelitian atau studi tentang Austronesia di situs-situs lain baik di wilayah Indonesia bagian barat maupun Indonesia bagian timur, sebagian besar masih terbatas pada budaya materinya atau artefaktualnya. Hal ini karena studi Austronesia di Indonesia belum berkembang, karena studi ini harus dilakukan secara komprehensif dengan melibatkan berbagai disiplin seperti misalnya linguistik, antropologi, paleoklimatologi, paleogeografi, 
paleoantropologi, paleontologi, dan genetika (Simanjuntak 2011, 7).

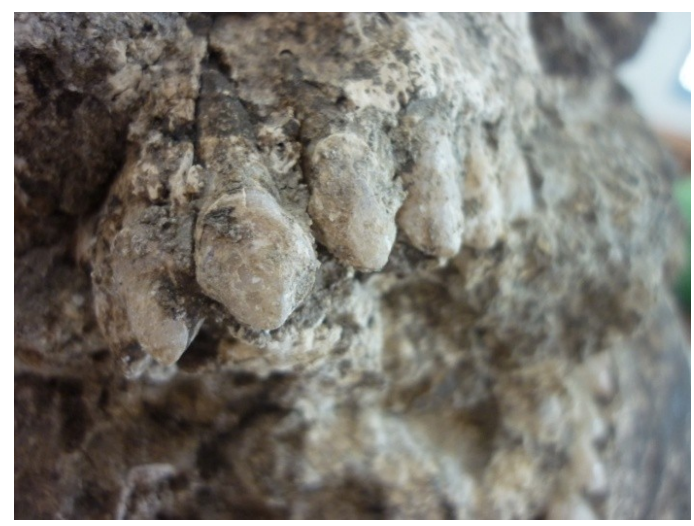

Foto 1. Modifikasi peruncingan gigi seri bagian atas pada individu Situs Binangun

(Dok. Balar Yogya)

\section{PENDUKUNG BUDAYA AUSTRONESIA DI PANTURA JAWA TENGAH}

Di atas telah disebutkan bahwa rentang waktu Austronesia Prasejarah di Indonesia antara 4000 - 2000 tahun BP. Berdasarkan model "Out of Taiwan" penutur bahasa AN adalah manusia ras Mongoloid yang bermigrasi ke selatan menuju Philippina dan kemudian sampai ke Kepulauan Indonesia serta Oseania. Perlu diketahui pula bahwa sebelum kedatangan migrant dari Taiwan, di wilayah kepulauan ini telah dihuni oleh ras Australomelanesid. Pada masa itu manusia yang mendiami kepulauan Indonesia dapat diketahui dari berbagai temuan sisa-sisa rangka manusia di berbagai tempat seperti misalnya di Anyer Lor (Jawa Barat), Puger (Jawa Timur), Gilimanuk (Bali), dan Plawangan, Jawa Tengah (Soejono 2008, 290). Baik rangka Anyer Lor maupun rangka Puger memperlihatkan

unsur Australomelanesid. Temuan rangka Gilimanuk lebih dari 100 individu selain masih memperlihatkan ciri-ciri Australomelanesid, akan tetapi dari muka dan giginya mulai banyak menampakkan ciri Mongolid. Sedangkan salah satu tengkorak temuan Situs Plawangan diketahui dari ras Mongoloid (Koesbardiati, T.; Murti, D.B.; Suriyanto, R.A. 2012, 135-142).

Di Indonesia, situs Austronesia Prasejarah jarang ditemukan, oleh karena itu Situs Plawangan yang terletak di Desa Plawangan, Kecamatan Kragan, Kabupaten Rembang, Jawa Tengah, merupakan situs yang menarik perhatian kita karena situs tersebut mewakili kelompok Austronesia Prasejarah. Sayang, situs tersebut saat ini sudah tidak dapat ditemu kenali lagi karena terdesak oleh kepentingan lain. Situs Plawangan yang terletak di pantai utara Jawa Tengah dapat diperkirakan sebagai salah satu tempat berlabuhnya para penutur bahasa AN yang masuk ke wilayah Indonesia. Seperti halnya Situs Plawangan, Situs Binangun dan Situs Leran yang terletak pada satu garis linear pantai utara Jawa Tengah diperkirakan sebagai permukiman manusia penutur bahasa AN.

Secara administratif, Situs Binangun berada di Desa Binangun, Kecamatan Lasem, Kabupaten Rembang, Jawa Tengah. Situs ini tepatnya terletak di antara Laut Jawa dan Jalan Raya Daendels kira-kira $6 \mathrm{Km}$ timur Kota Lasem. Tahun 2010 lokasi ini sempat menarik perhatian masyarakat karena ditemukannya beberapa potong tulang rangka manusia oleh seorang anak yang sedang bermain di pantai. Menindak lanjuti berita tentang temuan tersebut, Balai Arkeologi Yogyakarta mengirim Drs. Hari Lelono dan Drs. $\mathrm{H}$. Gunadi, M.Hum. untuk melakukan peninjauan temuan yang dicurigai bagian dari rangka manusia tersebut. Memperhatikan di sekitar lokasi temuan ditemukan sebaran pecahan tembikar dan cangkang moluska yang cukup padat, maka diperkirakan bahwa area ini merupakan situs arkeologi.

Ekskavasi Situs Binangun berhasil menemukan rangka manusia terdiri dari tulang kaki, pinggul, tulang belakang, tulang rusuk, dan tengkorak. Hasil analisis paleoantropologi yang dilakukan oleh tim dari Universitas Airlangga yang diketuai Dr.phil. Toetik Koesbardiati diketahui bahwa rangka manusia Situs Binangun berjenis laki-laki. Berdasarkan morfologi wajah individu Situs Binangun menunjukkan wajah yang sempit, sedangkan bentuk kepala dolichocephal atau lonjong, kedua karakter 


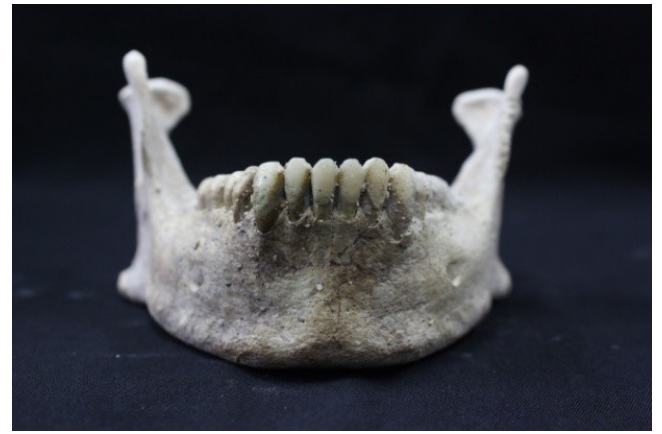

Foto 2. Modifikasi peruncingan gigi temuan dari Situs Semawang, Bali

Sumber: Toetik Koesbardiati \& Bayu D.M.

(Universitas Airlangga, Surabaya)

berkepala lonjong dan berwajah sempit merupakan ciri Australomelanesid. Oleh karena itu manusia dari Situs Binangun diduga berafinitas Australomelanesid. Hal menarik dari rangka Binangun adalah ditemukannya modifikasi buatan yaitu aktifitas pangur dan kerok pada gigigeligi. Pada gigi seri atas I1-I2 kanan-kiri, keempat gigi tersebut diruncingkan. Sedangkan indikasi kerokan ditemukan pada permukaan labial gigi rahang bawah, tetapi tidak ada praktik peruncingan. Model peruncingan gigi seperti ini ditemukan pula pada populasi paleometalik di Situs Semawang (Bali). Sedangkan pada populasi manusia hidup, modifikasi peruncingan gigi saat ini masih dapat ditemukan pada masyarakat Mentawai (Anonim 2012, 28-32).

Temuan rangka Situs Binangun dapat dipastikan merupakan sisa-sisa jasad manusia yang sengaja dikuburkan di tempat tersebut. Sistem penguburan membujur dengan arah hadap utara selatan mirip posisi makam pada pemakaman orang Islam. Oleh karena ciri-ciri fisik individu Situs Binangun secara paleoantropologis dapat dipastikan berasal dari masa paleome talik, maka orientasi kubur utara - selatan tidak dapat dikorelasikan dengan sistem penguburan pada masa Islam. Arah hadap kubur Situs Binangun dapat diorientasikan pada posisi Laut Jawa yang terletak di utara daratan Pulau Jawa. Orientasi bangunan prasejarah khususnya monument megalitik antara lain ke puncak gunung, benda-benda angkasa seperti matahari, bulan dan

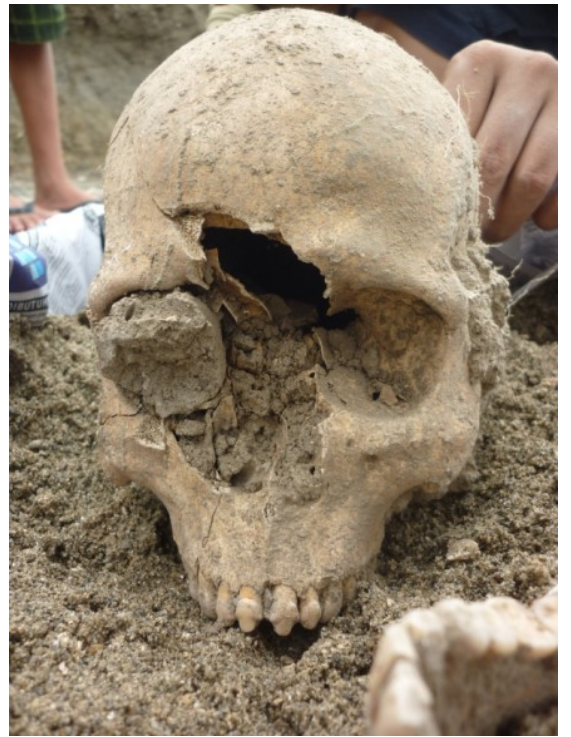

Foto 3. Modifikasi gigi bentuk kuncup bunga pada individu Leran 1

(Dok. Balar Yk)

bintang (Morris 1987), adapula yang berorientasi ke laut (Emory 1934).

Di Situs Leran, sisa-sisa rangka manusia ditemukan dalam jumlah cukup banyak, Situs Leran terletak di Desa Leran, Kecamatan Sluke, Kabupaten Rembang. Ada 4 (empat) individu ditemukan di situs tersebut, akan tetapi hanya satu rangka (Leran 4) yang ditemukan dari hasil ekskavasi. Sedangkan yang lain ditemukan dari tebing pantai yang longsor akibat abrasi dari gelombang air laut. Survei di Desa Leran menemukan data yang cukup signifikan yaitu sebaran sisa-sisa rangka manusia di sepanjang tebing pantai Leran. Sisa-sisa rangka manusia tersebut bermunculan di tebing pantai Leran akibat proses abrasi yang terjadi di kawasan tersebut. Selain sisa-sisa rangka manusia, pada lapisan yang sama ditemukan beberapa pecahan tembikar, alat dari cangkang moluska dan juga arang. Temuan arang sangat besar artinya dalam penelitian arkeologi karena material ini dapat digunakan sampel absolute dating.

Untuk memudahkan dalam diskripsi sisa-sisa rangka manusia Situs Leran, maka setiap individu diberi kode Leran 1 , 2, 3 dan seterusnya. Masing-masing individu dari rangka Situs Leran adalah sebagai berikut: 
a. Leran 1. Sisa rangka ini ditemukan pada koordinat $\mathrm{S} 06^{\circ} 38^{\prime} 22.8^{\prime \prime}$ dan $\mathrm{E}$ $111^{\circ} 28^{\prime}$ 06.3" terdiri dari beberapa tulang rusuk dan tengkorak yang relatif utuh. Posisi individu Leran 1 diperkirakan membujur dengan arah hadap utara-selatan sama dengan posisi Leran 4. Modifikasi gigi seri bagian atas (I1-I2) dibentuk mirip bentuk kuncup bunga. Modifikasi bentuk gigi pada masyarakat prasejarah pada umumnya adalah peruncingan, pencabutan, pengerokan, filing oklusal, filing labial, dan filing lingual. Modifikasi gigi seperti yang ditemukan pada individu Situs Binangun adalah biasa dilakukan oleh masyarakat prasejarah. Sedangkan modifikasi bentuk gigi seperti ditemukan pada individu Leran 1 dan Leran 2 sebelumnya di Indonesia belum pernah ditemukan, hal ini menarik untuk dilakukan studi lebih lanjut. Selain modifikasi gigi, dari individu Leran 1 diketahui pula adanya kolorasi gigi yang diakibatkan dari proses makan sirih pinang. Berdasarkan ciri yang ditemukan pada tengkorak Leran 1 dapat disimpulkan bahwa individu Leran 1 berjenis kelamin laki-laki dan cenderung berafinitas Australomelanesoid (Anonim 2012, 40-45).

b. Leran 2. Posisi individu Leran 2 yaitu S $06^{\circ} 38^{\prime} 22.4^{\prime \prime}$ dan E $111^{\circ} 28^{\prime} 06.8^{\prime \prime}$ sisa rangka yang dapat diselamatkan akibat abrasi air laut adalah tulang humerus. Sis-sia rangka lainnya masih tersimpan di dalam tanah dan tidak memungkinkan untuk diangkat, karena harus dilakukan secara sistematis melalui kegiatan ekskavasi. Hal ini tidak mungkin dapat dilakukan dalam waktu satu hari kerja. Salah satu bagian tengkorak yang terlihat pada permukaan dinding/tebing pantai adalah bagian rahang dan gigi depan. Terlihat bahwa salah satu gigi depan atas ditemukan adanya modifikasi gigi dengan bentuk kuncup bunga. Dari hasil pengamatan secara paleoantropologis berdasarkan caput humerus dapat diperkirakan bahwa individu Leran 2 adalah seorang laki- laki. Posisi tubuh Leran 2 diperkirakan membujur utara - selatan sama seperti halnya Leran 4 yaitu berorientasi ke Laut Jawa (Anonim 2012, 38-39).

c. Leran 3. Rangka ini terletak pada koordinat S $06^{\circ} 38^{\prime} 22.1^{\prime \prime}$ dan E $111^{\circ}$ 28' 06.8" sisa yang terlihat pada dinding atau tebing pantai adalah mandibula atau rahang bagian bawah. Sedangkan gigi-geliginya sudah lepas semua, sehingga tidak ada data yang dapat dikaji lebih jauh dari sisa rangka Leran 3. dapat dilakukan dalam waktu satu hari kerja. Salah satu bagian tengkorak yang terlihat pada permukaan dinding/tebing pantai adalah bagian rahang dan gigi depan. Terlihat bahwa salah satu gigi depan atas ditemukan adanya modifikasi gigi dengan bentuk kuncup bunga. Dari hasil pengamatan secara

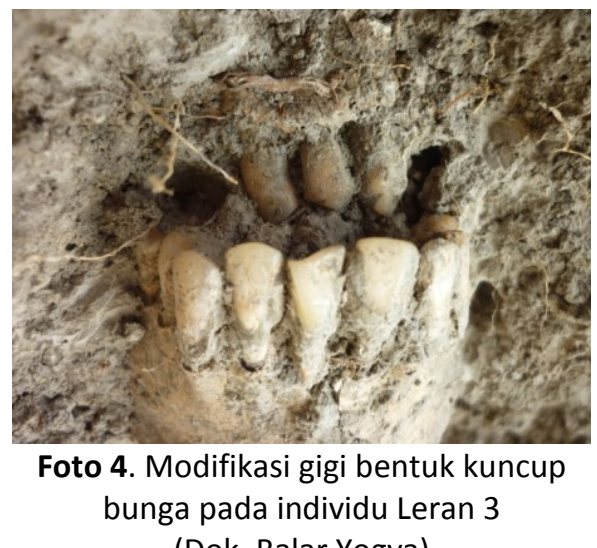

(Dok. Balar Yogya)

paleoantropologis berdasarkan caput humerus dapat diperkirakan bahwa individu Leran 2 adalah seorang lakilaki. Posisi tubuh Leran 2 diperkirakan membujur utara - selatan sama seperti halnya Leran 4 yaitu berorientasi ke Laut Jawa (Anonim 2012, 38-39).

d. Leran 4. Sisa-sisa rangka ini terletak pada posisi koordinat S $06^{\circ} 38^{\prime} 22.1^{\prime \prime}$ dan E $111^{\circ} 28^{\prime}$ 06.8'. Individu Leran 4 meliputi cranium, scapula, clavicula, thorax, humerus, radius, ulna, dan tulang belakang. Sedangkan sebagian tulang pinggul dan bagian kaki tertutup 
tanah pada kotak galian lain. Seperti individu Binangun, arah hadap rangka Leran 4 utara - selatan dan berorientasi pada Laut Jawa. Hasil analisis paleoantropologi diketahui bahwa individu Leran 4 berjenis kelamin perempuan, afinitas rasial Australomelanesoid dan tidak ditemukan modifikasi gigi seperti pada individu Binangun (Anonim 2012, Hal. 35-37).

Temuan rangka dari beberapa individu baik di Situs Binangun maupun Situs Leran menunjukkan bahwa di kawasan pantai Binangun maupun pantai Leran pernah tinggal komunitas manusia Austronesia Prasejarah. Keberadaan rangka manusia tersebut diperkuat dengan beberapa temuan artefaktual seperti misalnya pecahan tembikar dan alat yang terbuat dari kulit kerang yang merupakan ciri dari budaya Austronesia. Hasil analisis pertanggalan carbon 14 menunjukkan umur $2640 \pm 150$ BP (Sampel arang yang ditemukan pada satu level dengan temuan sisa rangka Leran 1 tersebut telah dianalisis di Laboratorium Radiocarbon Dating, Pusat Survey Geologi, Bandung). Apabila disejajarkan dengan individu yang ditemukan di Situs Leran, maka dapat di perkirakan kira-kira pada tahun $500 \mathrm{BC}$ para imigran penutur bahasa Austronesia telah mencapai pantai utara Jawa Tengah. Dengan demikian mereka diperkirakan datang dari Sulawesi atau Kalimantan, temuan alat dari cangkang moluska pelecypoda memperjelas bahwa komunitas manusia di Situs Leran cenderung berorientasi pada kehidupan laut. Arah hadap kubur yang berorientasi ke seberang lautan, merupakan konsep religi yang meyakini bahwa tanah asal mereka dari daerah di seberang lautan dan apabila meninggal jiwanya akan kembali ke tanah asal mereka. Rupa-rupanya kepercayaan seperti ini merupakan keyakinan yang universal bagi pendukung budaya Austronesia. Di Phillipina, kepercayaan seperti di atas lebih eksplisit dengan visualisasi bentuk kubur yang menyerupai perahu (stone boat shape burial) seperti yang ditemukan di Pulau Batan, Sabtang, dan Ibuhos (Dizon, Eusebio Z., 1996-
1997). Data arkeologis seperti yang

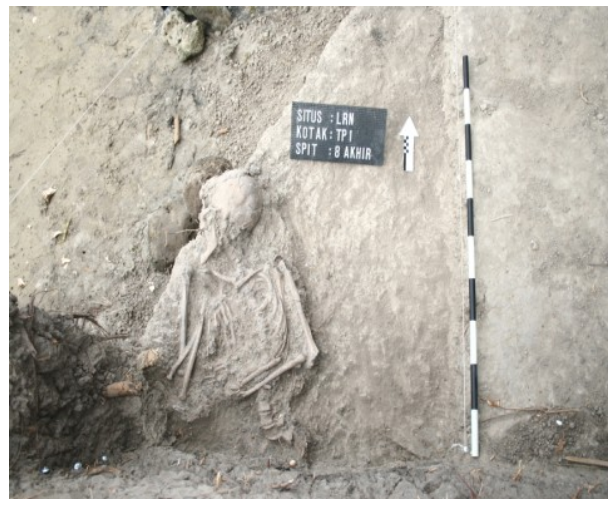

Foto 5. Rangka Leran 4 hasil ekskavasi TP 1

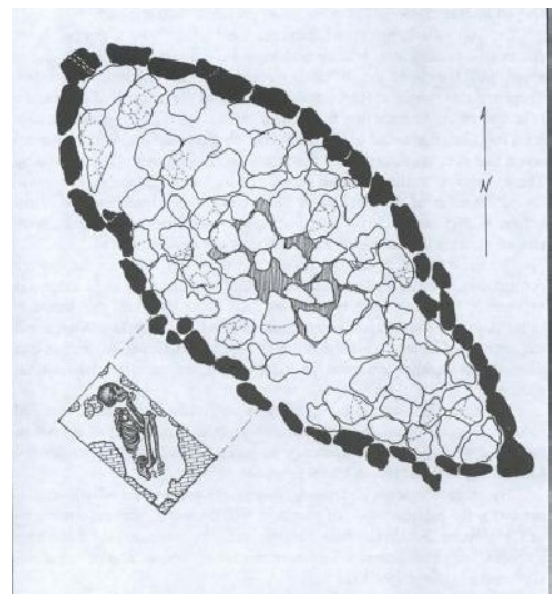

Foto 6. Kubur batu berbentuk perahu di P. Batanes

(Sumber: Dizon 1996-1997)

ditemukan di kepulauan Batanes memperkuat bahwa leluhur bangsabangsa penutur bahasa Austronesia adalah para imigran "manusia perahu" yang berasal dari luar Asia Tenggara, yang oleh Peter Bellwood diyakini tanah asal mereka adalah Taiwan.

\section{PENUTUP}

Mengapa manusia Austronesia mendiami Binangun, Leran dan Plawangan? Karena mereka melihat Gunung Lasem. Berdasarkan peta di atas diketahui bahwa Gunung Lasem berada di dekat pantai sehingga akan terlihat oleh para pelaut yang melintasi Laut Jawa. Dengan berpatokan Gunung Lasem itulah para imigran Austronesia akhirnya menemukan pantai Binangun, Leran dan Plawangan untuk lokasi berlabuh. Berdasarkan ciri-ciri budaya 
baik yang bersifat tangible maupun intangible, rangka manusia yang ditemukan di Situs Binangun dan Situs Leran dapat diperkirakan individu-individu pendukung budaya Austronesia. Data intangible seperti kebiasaan makan sirih yang diketahui dari kerak gigi rangka Leran 1 dan Leran 3. Sedangkan data tangible misalnya temuan alat kerang, fragmen tembikar slip merah, dan tembikar berhias. Mereka mendiami daerah tersebut sejak 500 tahun BC. Informasi ini merupakan data baru untuk rekonstruksi sejarah pendukung budaya Austronesia di Jawa khususnya dan Indonesia pada umumnya.

Atas dasar hasil penelitian seperti telah diuraikan sebelumnya, maka dapat disimpulkan bahwa pantai utara Jawa Tengah khususnya di sekitar pegunungan Lasem Utara adalah wilayah yang memungkinkan untuk "pelabuhan" para pelaut Austronesia yang mencari daerahdaerah baru untuk kehidupan mereka. Mengacu pada hasil analisis carbon (C14) dapat disimpulkan pula bahwa individu-individu yang ditemukan di Binangun dan Leran tidak berasal dari Gilimanuk (Bali) ataupun dari Anyer (Jawa Barat), akan tetapi mereka datang dari Sulawesi atau Kalimantan.

Apabila penelitian ini dikaitkan dengan isu-isu tentang penutur rumpun bahasa Austronesia yang masih penuh dengan berbagai pertanyaan penelitian, maka penelitian ini ibarat mata rantai yang siap disambungkan dengan mata rantai yang lain yaitu situs-situs Austronesia di tempat lain yang seumur. Demikian pula dalam skala makro ataupun meso Situs Binangun dan Situs Leran yang merupakan situs penguburan dapat dilengkapi dengan mencari factor atau indikator lain yang dapat menjelaskan tentang permukiman bangsa-bangsa penutur bahasa Austronesia di kawasan pantai utara, seperti misalnya lokasi hunian atau tempat tinggal dan apabila memungkinkan mencari bentuk rumah dan populasi dan pola permukimannya.

\section{UCAPAN TERIMA KASIH}

Penulis mengucapkan banyak terima kasih kepada seluruh anggota tim penelitian Situs Binangun, Leran, dan Plawangan 2012 baik rekan-rekan dari Balai Arkeologi Yogyakarta, Fakultas IImu Budaya, Universitas Gadjah Mada, Fakultas Sosial dan IImu Politik, Universitas Airlangga, Pemerintah Kabupaten Rembang dan teman-teman dari Lasem Heritage Society. Tidak lupa terima kasih kepada masyarakat Binangun, Leran dan Plawangan yang dengan antusias memberikan informasi sangat berharga bagi kelancaran penelitian kami. 


\section{DAFTAR PUSTAKA}

Anonim. 2012. "Penelitian Situs Kubur Prasejarah Di Pantai Utara Kabupaten Rembang, Jawa Tengah". Laporan Penelitian Arkeologi. Balai Arkeologi Yogyakarta (Belum Diterbitkan).

Bellwood, Peter. 1995/2006. "Austronesian Prehistory in Southeast Asia: Homeland, Expansion and Transformation" dalam Peter Bellwood, James J. Fox and Darrell Tryon (ed.) The Austronesians, Historical and Comparative Perspective. Canberra: E-PRESS, The Australian National University.

Bellwood, Peter, 2000. Prasejarah Kepulauan Indo-Malaysia (Edisi Revisi). Jakarta: PT. Gramedia Pustaka Utama.

Dizon, Eusebio Z. 1996 - 1997. "Archaelology Of Batanes Province, Northern Philippines" dalam The 1996 - 1997 Status Report, Archaeology Division and Underwater Archaeology Section. Manila: National Museum of The Philippines.

Emory, Kenneth P. 1934. Archaeology Of The Pacific Equatorial Islands. Honolulu: The Museum.

Fernandez, Inyo Yos. 2004. "Asal Mula Orang Austronesia" dalam Polemik tentang Masyarakat Austronesia. Jakarta: Lembaga IImu Pengetahuan Indonesia bekerjasama dengan Direktorat Jenderal Pendidikan Tinggi, Departemen Pendidikan Nasional.

Geldern, Robert von Heine. 1945. "Prehistoric Research in the Netherlands Indies" dalam Pieter Honig and Frans Verdoorn (ed.) Science and Scientists in the Netherlands Indies. New York Board for the Netherlands Indies.

Hoop, A.N.J. Th a Th Van Der. 1938. "De Praehistorie" dalam Geschiedenis Van Nederlandsch Indie. Amsterdam: N.V. Uitgeversmaatschappij-Joost Van Den Vondel,.

Koentjaraningrat, 1982. Manusia dan Kebudayaan di Indonesia. Jakarta: Penerbit Djambatan.

Koesbardiati, T., Murti, B.D., Suriyanto, R.A. 2012. "Leprosy On Plawangan Skull: Evidences For Mongoloidization?" dalam The International Seminar Proceeding Book, Celebrating the $80^{\text {th }}$ birthday of Professor Dr. Habil Josef Glinka, SVD. Surabaya: Department of Anthropology, Faculty of Social and Political Sciences, Airlangga University. HIm. 135-141.

Masinambow, E.K.M. 2004. "Masyarakat Austronesia: Fakta atau Fiksi?" dalam Polemik tentang Masyarakat Austronesia. Jakarta: Lembaga IImu Pengetahuan Indonesia bekerjasama dengan Direktorat Jenderal Pendidikan Tinggi, Departemen Pendidikan Nasional.

Morris, lan. 1987. Burial and Ancient Society. Cambridge: Cambridge University Press.

Simanjuntak, Truman, 2007. Arkeologi \& Etnografi Kalumpang Kabupaten Mamuju Provinsi Sulawesi Barat. Jakarta: Pusat Penelitian Arkeologi Nasional. 
2008 (ed.). Austronesian in Sulawesi. Jakarta: Center for Prehistoric and Austronesian Studies.

2011. "Austronesia Prasejarah di Indonesia" dalam Austronesia \& Melanesia di Nusantara. Yogyakarta: Penerbit Ombak.

Soejono, R. P. 2008. "Zaman Prasejarah Indonesia", Sejarah Nasional Indonesia I, Jakarta: Penerbit Balai Pustaka.

Sukendar, Haris dan Awe, Rokhus Due. 1981. "Laporan Penelitian Terjan dan Plawangan Jawa Tengah". Berita Penelitian Arkeologi No. 27, Jakarta: Proyek Penelitian Purbakala Jakarta, Departemen Pendidikan dan Kebudayaan.

Tanudirdjo, Daud Aris dan Prasetyo, Bagyo. 2004. "Model Out of Taiwan" dalam Polemik tentang Masyarakat Austronesia, Jakarta: Lembaga IImu Pengetahuan Indonesia bekerjasama dengan Direktorat Jenderal Pendidikan Tinggi, Departemen Pendidikan Nasional. 